\title{
PEMETAAN POTENSI LAHAN DAN SEBARAN POPULASI \\ TANAMAN RASAMALA UNTUK PENGEMBANGAN SUMBER BENIH DI JAWA
}

\author{
Mapping of the Potency of Site and Population for Seed Source Establishment \\ of Rasamala in Java
}

Danu, Asep Rohandi dan/and Agus Astho Pramono

Balai Penelitian Teknologi Perbenihan Bogor

Jl. Pakuan, Ciheuleut PO. BOX 105, Bogor 16001

Telp./Fax. (0251) 8327768

Naskah masuk: 23 Juni 2008 ; Naskah diterima: 17 Februari 2009

\begin{abstract}
Research activity on mapping of site and population of rasamala (Altingia excelsa Noronhae) in Java was aimed to map its forest distribution, either in its natural population or plantation forest, as well as its ecological information (geography, climate, soil) for establishment and development rasamala plantation forest in Java island. Data was obtained from: (1) literature review and personal communication; (2) site condition (geography, climate, rain, soil and topography); (3) stand condition. Geographical Information System (GIS) was used for mapping of population distribution of rasamala and its potential sites. Result of the research showed that potential seed sources of rasamala were found in Bandung, Garut, Cianjur, and Banyumas districts. They were distributed at $808-1962 \mathrm{~m}$ above sea level in several types of soil (Latosol, Grumusol, association of Andosol and Latosol, association of Regosol and Litosol soils), with annual precipitation of 1500 - $4300 \mathrm{~mm} /$ year. Result of GIS analysis showed that there are area of 1,708,756 hectares as potential sites to develop rasamala seed source. The total area of certified and mapped rasamala seed source was 118.78 hectares.
\end{abstract}

Keywords: rasamala (Altingia excelsa Noronhae), mapping of population, seed source, site potential

\begin{abstract}
ABSTRAK
Kegiatan penelitian pemetaan sebaran populasi tanaman hutan untuk sumber benih jenis rasamala (Altingia excelsa Noronhae) bertujuan untuk mengetahui sebaran populasi tanaman rasamala, baik yang terdapat di hutan alam maupun hutan tanaman beserta informasi kondisi ekologis tempat tumbuhnya seperti letak geografis, kondisi iklim, curah hujan dan jenis tanah sehingga dapat diketahui potensi lahan untuk pengembangan jenis ini di Pulau Jawa. Metode pengumpulan data meliputi: (1) studi literatur dan komunikasi langsung dengan pihak terkait dan masyarakat, (2) pengumpulan data sekunder meliputi: letak geografis, ketinggian, curah hujan, jenis tanah, dan topografi, (3) pengumpulan data kondisi tegakan meliputi: tahun tanam, kerapatan tegakan, tinggi, diameter, bentuk batang, bentuk tajuk. Penyusunan peta sebaran populasi dan potensi lahan jenis rasamala dengan menggunakan Sistem Informasi Geografis (SIG). Hasil penelitian menunjukkan bahwa potensi populasi rasamala untuk sumber benih tersebar di beberapa kabupaten yaitu kabupaten Bandung, Garut, Cianjur dan Banyumas. Lahan tersebut terletak pada ketinggian 808-1962 m dpl, jenis tanah Latosol, Litosol, Grumusol, asosiasi Andosol dan Latosol, asosiasi Regosol dan Litosol dengan curah hujan 1500-4300 mm/tahun. Hasil analisis SIG menunjukkan sebaran potensi lahan untuk pengembangan tanaman rasamala di Pulau
\end{abstract}


Jawa seluas 1.708 .756 ha. Sementara itu, ketersediaan sumber benih rasamala yang telah disertifikasi dan dapat dipetakan seluas 118,74 ha. $\begin{array}{ll}\text { Kata kunci : } & \begin{array}{l}\text { Peta sebaran populasi, sumber benih, potensi lahan, rasamala (Altingia excelsa } \\ \text { Noronhae) }\end{array}\end{array}$

\section{PENDAHULUAN}

\section{A. Latar Belakang}

Upaya pembangunan hutan tanaman maupun rehabilitasi lahan menuntut ketersediaan benih berkualitas yang memiliki kemampuan adaptasi terhadap lingkungan dan nilai manfaat yang tinggi. Sementara itu, areal penanaman hutan umumnya terletak pada lokasi yang marginal dan miskin hara. Salah satu kegiatan yang berperan sangat penting dalam memberdayakan jenis-jenis pohon yang potensial adalah pemetaan sebaran populasi sumber benihnya (Zobel and Talbert, 1991; Kartiko, 2001). Peta sebaran populasi ini dapat digunakan sebagai dasar untuk pemilihan sumber benih yang tepat. Penggunaan sumber benih yang tepat merupakan salah satu dasar yang sederhana dan mudah dalam usaha perbaikan tanaman hutan (Nienstadt dan Snyder, 1974).

Tanaman rasamala (Altingia excelsa Noronhae), famili Hamamelidaceae, memiliki nilai ekonomi tinggi terutama untuk daerah dataran tinggi. Rasamala tumbuh tersebar secara alami di Bhutan, Assam, Pegu, Mergui, Malaysia dan Indonesia (Beekman, 1949; Vink, 1957). Di Indonesia, rasamala tumbuh secara alami di Aceh, Pegunungan Bukit Barisan, Banten Selatan dan Priangan (Jawa Barat) yang tersebar pada ketinggian 700-1700 m dpl, dengan tanah yang subur dan lembab (Beekman, 1947; Widjajanto, 1984). Kayu rasamala termasuk kelas awet II-III dan kelas kuat II, tahan terhadap serangan bubuk kayu kering dan rayap, sehingga dapat digunakan untuk konstruksi berat (jembatan) dan bahan bangunan (Oey, 1951; Vink, 1957; Direktorat Jenderal Kehutanan, 1979). Rasamala berbunga dan berbuah setiap waktu meskipun tidak sebanyak pada musimnya, jumlah terbanyak terjadi pada bulan April dan Mei, buah yang sudah tua pada umumnya jatuh pada bulan Agustus (Kramer, 1926; Beekman, 1947).

Sampai saat ini tegakan rasamala di Pulau Jawa masih cukup luas, baik dalam bentuk hutan alam maupun hutan tanaman. Namun populasinya terus menurun dan kondisi sebaran alami saat ini belum teridentifikasi secara jelas, sehingga perlu dilakukan penelitian pemetaan sebaran populasi untuk pengembangan sumber benih. Ruang lingkup kegiatan ini meliputi: (a) pembuatan peta sebaran tanaman dan zonasi ekologi tanaman rasamala berdasarkan Sistem Informasi Geografis (SIG) dan data ekologinya; (b) interpretasi data zonasi ekologi sumber benih dan potensi lahan hutan tanaman rasamala.

\section{B. Tujuan Penelitian}

Mengetahui sebaran populasi dan potensi lahan tanaman rasamala di Pulau Jawa, baik yang terdapat di hutan alam maupun hutan tanaman beserta informasi geografi dan konsisi ekologisnya sebagai dasar dalam pengembangan sumber benih dan hutan tanaman jenis ini.

\section{BAHAN DAN METODE}

\section{A. Pengumpulan Data}

Pengumpulan data potensi lahan dan sebaran populasi jenis rasamala meliputi data sekunder dan primer lapangan. Data sekunder diperoleh dari studi literatur dan komunikasi langsung dengan beberapa pakar yang mengetahui mengenai jenis yang dimaksud. Data sekunder yang dikumpulkan meliputi: jenis tanaman yang berasosiasi, luas wilayah, lokasi (letak geografis, wilayah administrasi pemerintahan, wilayah kehutanan), kondisi ekologis (jenis tanah, ketinggian, curah hujan, kelerengan), 
potensi produksi, musim buah serta sistem silvikultur yang digunakan, sebaran populasi (hutan alam dan hutan tanaman). Peta yang digunakan meliputi peta administrasi, peta tanah, data iklim berupa peta curah hujan, peta kelas ketinggian, peta land use (penggunaan lahan) wilayah Jawa, serta peta zonasi benih tanaman hutan wilayah Jawa - Madura sebagai penunjang. Data sekunder diperoleh dari berbagai instansi, antara lain: Perum Perhutani, Direktorat Jenderal Rehabilitasi Lahan dan Perhutanan Sosial (RLPS), Balai Penelitian Teknologi Perbenihan (BPTP), Balai Perbenihan Tanaman Hutan (BPTH), Pusat Penelitian Tanah dan Agroklimat, Bakosurtanal, Badan Planologi Departemen Kehutanan dan instansi terkait lainnya.

Data primer dikumpulkan melalui survei lapangan untuk: (1) mengidentifikasi kondisi dan sebaran populasi jenis rasamala yang tersebar di beberapa lokasi wilayah Jawa meliputi : letak geografis, iklim, jenis tanah, topografi, wilayah administrasi pemerintahan, (2) mengidentifikasi luas lahan yang dapat ditanami jenis rasamala, (3) mengidentifikasi kondisi tegakan, pembungaan dan pembuahan. Bahan dan alat untuk survei lapangan dan laboratorium: GPS (Global Positioning System), teropong, hagameter, altimeter, alat tulis dan lain-lain.

\section{B. Penyusunan Peta Sebaran dan Potensi Lahan Jenis Rasamala} berikut :

Penyusunan peta dilakukan berdasarkan data-data yang diperoleh, dengan tahapan sebagai

1. Peta sebaran populasi untuk sumber benih disusun dengan memetakan/plotting data lokasilokasi sebaran populasi yang meliputi letak geografis/letak wilayah administratifnya pada peta administrasi wilayah Pulau Jawa.

2. Penilaian potensi lahan dilakukan melalui tumpang susun/overlay peta yang berbeda berupa peta lereng, peta ketinggian, peta tanah dan peta iklim (data curah hujan) dengan menggunakan Sistem Informasi Geografis (SIG). Wilayah penelitian dibatasi/diseleksi berdasarkan peta land use (penggunaan lahan) sehingga wilayah-wilayah yang sudah tidak bisa diubah seperti pemukiman, tubuh air, sawah dan wilayah lain yang dianggap kurang memungkinkan untuk pengembangan jenis tanaman kehutanan tidak termasuk pada wilayah penelitian. Satuan lahan yang terbentuk akan dinilai berdasarkan sifat-sifat atau karakteristik (kualitas lahan) yang kemudian akan dibandingkan (matching) dengan persyaratan pertumbuhan tanaman untuk masing-masing jenis dan pembatas penggunaan lahan sehingga akan tersusun peta potensi lahan jenis rasamala.

3. Untuk menghasilkan peta sebaran populasi dan sekaligus potensi lahan jenis rasamala di wilayah Jawa dibuat dengan cara overlay antara peta sebaran populasi dengan peta potensi lahan rasamala.

\section{HASIL DAN PEMBAHASAN}

\section{A. Hasil}

\section{Sebaran Populasi Tanaman Rasamala}

Tegakan rasamala di pulau Jawa secara umum terdapat pada wilayah kerja Perum Perhutani Unit III Jawa Barat dan Unit I Jawa Tengah. Populasi rasamala di Jawa Barat tersebar di beberapa KPH yaitu KPH Bogor, KPH Sukabumi, KPH Cianjur, KPH Bandung dan KPH Garut. Sementara itu, untuk wilayah Jawa Tengah populasi rasamala tersebar di KPH Banyumas Barat dan KPH Banyumas Timur. Tegakan ini merupakan tegakan sumber benih rasamala dan tegakan yang berpotensi untuk dikembangkan sebagai sumber benih. Letak administratif dan geografis lokasi sebaran populasi rasamala di Pulau Jawa selengkapnya disajikan pada Tabel 1. 
Tabel (Table) 1. Letak administratif dan geografis lokasi sebaran populasi rasamala di Pulau Jawa (Administrative and geographical position of distribution location of rasamala population in Java Island)

\begin{tabular}{|c|c|c|c|}
\hline No. & $\begin{array}{l}\text { Kabupaten } \\
\text { (District) }\end{array}$ & $\begin{array}{c}\text { Letak Geografis } \\
\text { (Geographical position) }\end{array}$ & $\begin{array}{c}\text { Wilayah Kehutanan } \\
\text { (Administrative forestry area) }\end{array}$ \\
\hline \multirow[t]{2}{*}{1.} & \multirow[t]{2}{*}{ Bandung } & $\begin{array}{r}07^{0} 08^{\prime} 313^{\prime \prime} \mathrm{LS} \\
107^{0} 31^{\prime} 137^{\prime \prime} \mathrm{BT}\end{array}$ & $\begin{array}{l}\text { Petak 26a, RPH Gambung, BKPH } \\
\text { Ciwidey }\end{array}$ \\
\hline & & $\begin{array}{r}07^{0} 07^{\prime} 406^{\prime \prime} \mathrm{LS} \\
107^{0} 30^{\prime} 848^{\prime \prime} \mathrm{BT}\end{array}$ & $\begin{array}{l}\text { Petak 27b, RPH Gambung, BKPH } \\
\text { Ciwidey }\end{array}$ \\
\hline \multirow[t]{3}{*}{2.} & \multirow[t]{3}{*}{ Garut } & $\begin{array}{r}07^{\circ} 23^{\prime} 210^{\prime \prime} \text { LS } \\
107^{\circ} 48^{\prime} 280^{\prime \prime} \text { BT } \\
\end{array}$ & RPH Cikajang, BKPH Cikajang \\
\hline & & $\begin{array}{r}07^{\circ} 20^{\prime} 330^{\prime \prime} \text { LS } \\
107^{\circ} 44^{\prime} 280^{\prime \prime} \text { BT }\end{array}$ & RPH Cikandang, BKPH Cikajang \\
\hline & & $\begin{array}{r}07^{\circ} 19^{\prime} 430^{\prime \prime} \mathrm{LS} \\
107^{\circ} 44^{\prime} 560^{\prime \prime} \mathrm{BT}\end{array}$ & RPH Sumadra, BKPH Sumadra \\
\hline 3. & Sukabumi & $\begin{array}{r}06^{0} 59^{\prime} 963^{\prime \prime} \mathrm{LS} \\
107^{0} 00^{\prime} 880^{\prime \prime} \mathrm{BT} \\
\end{array}$ & RPH Takokak, BKPH Cikawung \\
\hline \multirow[t]{7}{*}{4.} & \multirow[t]{7}{*}{ Cianjur } & $\begin{array}{r}07^{0} 05^{\prime} 390^{\prime \prime} \mathrm{LS} \\
107^{0} 03^{\prime} 114^{\prime \prime} \mathrm{BT} \\
\end{array}$ & $\begin{array}{l}\text { Petak 19.F Pasir Kuda, RPH Takokak, } \\
\text { BKPH Sukanagara Selatan }\end{array}$ \\
\hline & & $\begin{array}{r}07^{0} 07^{\prime} 172^{\prime \prime} \text { LS } \\
107^{0} 04^{\prime} 307^{\prime} \text { BT } \\
\end{array}$ & $\begin{array}{l}\text { Petak 14.B Ciputri, RPH Takokak, BKPH } \\
\text { Sukanagara Selatan }\end{array}$ \\
\hline & & $\begin{array}{r}07^{0} 06^{\prime} 535^{\prime} \text { ' LS } \\
107^{0} 03^{\prime} 535^{\prime} \text { BT }\end{array}$ & $\begin{array}{l}\text { Petak 13.C, RPH Takokak, BKPH } \\
\text { Sukanagara Selatan }\end{array}$ \\
\hline & & $\begin{array}{r}07^{0} 06^{\prime} 317^{\prime \prime} \mathrm{LS} \\
107^{0} 03^{\prime} 317^{\prime \prime} \mathrm{BT} \\
\end{array}$ & $\begin{array}{l}\text { Petak 13.A Ciengang, RPH Takokak, } \\
\text { BKPH Sukanagara Selatan }\end{array}$ \\
\hline & & $\begin{array}{r}06^{0} 58^{\prime} 535^{\prime \prime} \mathrm{LS} \\
107^{0} 08^{\prime} 364^{\prime \prime} \mathrm{BT} \\
\end{array}$ & $\begin{array}{l}\text { Petak 28.A Cicadas, RPH Cibeber, BKPH } \\
\text { Sukanagara Utara }\end{array}$ \\
\hline & & $\begin{array}{r}05^{0} 59^{\prime} 064^{\prime \prime} \mathrm{LS} \\
107^{0} 08^{\prime} 301^{\prime \prime} \mathrm{BT} \\
\end{array}$ & $\begin{array}{l}\text { Petak 28.B Cicadas, RPH Cibeber, BKPH } \\
\text { Sukanagara Utara }\end{array}$ \\
\hline & & $\begin{array}{r}07^{0} 03^{\prime} 309^{\prime \prime} \mathrm{LS} \\
107^{0} 08^{\prime} 166^{\prime \prime} \mathrm{BT} \\
\end{array}$ & $\begin{array}{l}\text { Petak 46.C Sukarajin, RPH Campaka, } \\
\text { BKPH Sukanagara Utara }\end{array}$ \\
\hline 5. & Banyumas & $\begin{array}{r}07^{0} 20^{\prime} 703^{\prime \prime} \mathrm{LS} \\
109^{0} 44^{\prime} 990^{\prime \prime} \mathrm{BT}\end{array}$ & RPH Sewu, BKPH Karang Kobar \\
\hline
\end{tabular}

Berdasarkan data yang diperoleh, sejak tahun 1931 sampai tahun 2003 jenis ini sudah ditanam di KPH Cianjur seluas 5.127,9 ha, KPH Sukabumi seluas 793,6 ha, KPH Banyumas Timur seluas 104,1 ha, KPH Bandung Selatan seluas 2.632,78 ha. Tanaman ini tumbuh baik dan tersebar pada kondisi tempat tumbuh seperti yang tercantum pada Tabel 2. 
Tabel (Table) 2. Kondisi tempat tumbuh jenis Rasamala (Altingia excelsa) pada beberapa lokasi di Pulau Jawa (Site condition of rasamala on several locations in Java)

\begin{tabular}{|c|l|l|c|c|}
\hline No. & \multicolumn{1}{|c|}{$\begin{array}{c}\text { Lokasi } \\
\text { (Location) }\end{array}$} & \multicolumn{1}{|c|}{$\begin{array}{c}\text { Jenis Tanah } \\
\text { (Soil type })\end{array}$} & $\begin{array}{c}\text { Ketinggian } \\
\text { (Altitude }) \\
(\mathrm{m} \mathrm{dpl}) /(\mathrm{m} \text { asl })\end{array}$ & $\begin{array}{c}\text { Curah Hujan } \\
\text { (Rainfall) } \\
(\mathrm{mm} / \text { tahun }) /(\text { mm/year })\end{array}$ \\
\hline 1. & Garut & $\begin{array}{l}\text { Latosol, Litosol, Grumosol, } \\
\text { Asosiasi Andosol dan Latosol, } \\
\text { Asosiasi Regosol dan Litosol }\end{array}$ & $1100-1600$ & $2640-3360$ \\
\hline 2. & Bandung & $\begin{array}{l}\text { Andosol dan Latosol, Regosol, } \\
\text { Andosol }\end{array}$ & $1200-1500$ & $1500-5200$ \\
\hline 3. & Cianjur & Grumosol, Mediterian & $808-1039$ & 3080 \\
\hline 4. & Sukabumi & Grumosol, Mediterian & 1100 & 3080 \\
\hline 5. & Banyumas & Latosol & $965-1962$ & 4300 \\
\hline
\end{tabular}

Sumber/Source: Survei dan Risalah Hutan KPH Garut, Bandung Selatan, Cianjur, Sukabumi, dan Banyumas

Berdasarkan sebaran sumber benih dan populasi rasamala di Pulau Jawa (Tabel 1) dan data kondisi ekologis untuk masing-masing lokasi (Tabel 2), maka secara umum kriteria persyaratan tumbuh jenis rasamala seperti tercantum pada Tabel 3 .

Tabel (Table) 3. Kriteria persyaratan tumbuh tanaman jenis rasamala (A. excelsa) (Criteria of site requirement of rasamala (A. excelsa))

\begin{tabular}{|l|c|c|}
\hline \multicolumn{1}{|c|}{$\begin{array}{c}\text { Jenis Tanah } \\
\text { (Soil type })\end{array}$} & $\begin{array}{c}\text { Ketinggian } \\
(\text { Altitude }) \\
(\mathrm{m} \mathrm{dpl}) /(\text { m asl })\end{array}$ & $\begin{array}{c}\text { Curah Hujan } \\
(\text { Rainfall }) \\
(\mathrm{mm} / \text { tahun }) /(\text { mm/year })\end{array}$ \\
\hline $\begin{array}{l}\text { Latosol, Litosol, Grumosol, Asosiasi } \\
\text { Andosol dan Latosol, Asosiasi Regosol } \\
\text { dan Litosol, Mediteran }\end{array}$ & $808-1962$ & $1500-4300$ \\
\hline
\end{tabular}

Keterangan/Note: Jenis tanah berdasarkan sistem klasifikasi Dudal Soepraptohardjo (Hardjowigeno, 2003) (Soil types based on classification system by Dudal Soepraptohardjo)

\section{Potensi Lahan Tanaman Rasamala}

Kesesuaian lahan merupakan gambaran tingkat kecocokan sebidang lahan untuk penggunaan tertentu (Sitorus, 1998). Selanjutnya Hardjowigeno (2003) menjelaskan bahwa tujuan dari evaluasi lahan adalah menentukan nilai potensi suatu lahan untuk tujuan tertentu. Evaluasi kesesuaian atau kemampuan lahan dilakukan dengan cara membandingkan persyaratan penggunaan lahan dengan kualitas (karakteristik) lahannya.

Berdasarkan kriteria Tabel 3, hasil analisis SIG menunjukkan bahwa potensi lahan jenis rasamala di Pulau Jawa seluas 1.193.266,67 ha yang tersebar di 37 kabupaten (Tabel 4 dan Gambar 2).

Data luas potensi lahan pada Tabel 4 merupakan lokasi/wilayah yang potensial dan memungkinkan untuk pengembangan jenis rasamala. Wilayah-wilayah seperti pemukiman, jalan, sungai, danau, sawah dan wilayah lain yang tidak memungkinkan untuk pengembangan tanaman kehutanan, tidak dimasukkan dalam penilaian. 
Tabel (Table) 4. Luas potensi lahan jenis rasamala (A. excelsa) di pulau Jawa (Potential land area of rasamala (A. excelsa) in Java island)

\begin{tabular}{|r|l|r|r|l|r|}
\hline No. & \multicolumn{1}{|c|}{$\begin{array}{c}\text { Kabupaten } \\
(\text { District })\end{array}$} & Luas (Ha) & No. & $\begin{array}{c}\text { Kabupaten } \\
(\text { District })\end{array}$ & Luas (Ha) \\
\hline 1 & Banjarnegara & $40.039,81$ & 21. & Bandung & $219.637,63$ \\
\hline 2 & Banyumas & $14.089,26$ & 22. & Batu & $38.181,80$ \\
\hline 3 & Banyuwangi & $51.517,36$ & 23. & Blitar & $17.157,82$ \\
\hline 4 & Batang & $17.816,17$ & 24. & Bogor & $32.054,77$ \\
\hline 5 & Bondowoso & $53.684,60$ & 25. & Madiun & $6.599,49$ \\
\hline 6 & Boyolali & $22.454,20$ & 26. & Magelang & $43.229,24$ \\
\hline 7 & Brebes & $9.059,28$ & 27. & Pasuruan & $33.752,36$ \\
\hline 8 & Ciamis & $23.558,35$ & 28. & Probolinggo & $51.315,34$ \\
\hline 9 & Cianjur & $67.046,36$ & 29. & Salatiga & $35.493,87$ \\
\hline 10 & Cilacap & 98,88 & 30. & Sukabumi & $57.456,02$ \\
\hline 11 & Garut & $132.319,54$ & 31. & Kudus & $2.341,73$ \\
\hline 12 & Gunung Kidul & 583,01 & 32. & Kulon Progo & $1.184,50$ \\
\hline 13 & Jember & $47.533,20$ & 33. & Kuningan & $15.667,50$ \\
\hline 14 & Jepara & $5.923,99$ & 34. & Lebak & $9.829,49$ \\
\hline 15 & Jombang & $6.544,04$ & 35. & Lumajang & $41.209,58$ \\
\hline 16 & Karanganyar & $20.471,71$ & 36. & Magetan & $13.358,69$ \\
\hline 17 & Kebumen & 97,75 & 37. & Majalengka & $30.492,12$ \\
\hline 18 & Kediri & $15.319,97$ & & & \\
\hline 19 & Kendal & $12.856,76$ & & & \\
\hline 20 & Klaten & $3.290,48$ & & & \\
\hline
\end{tabular}

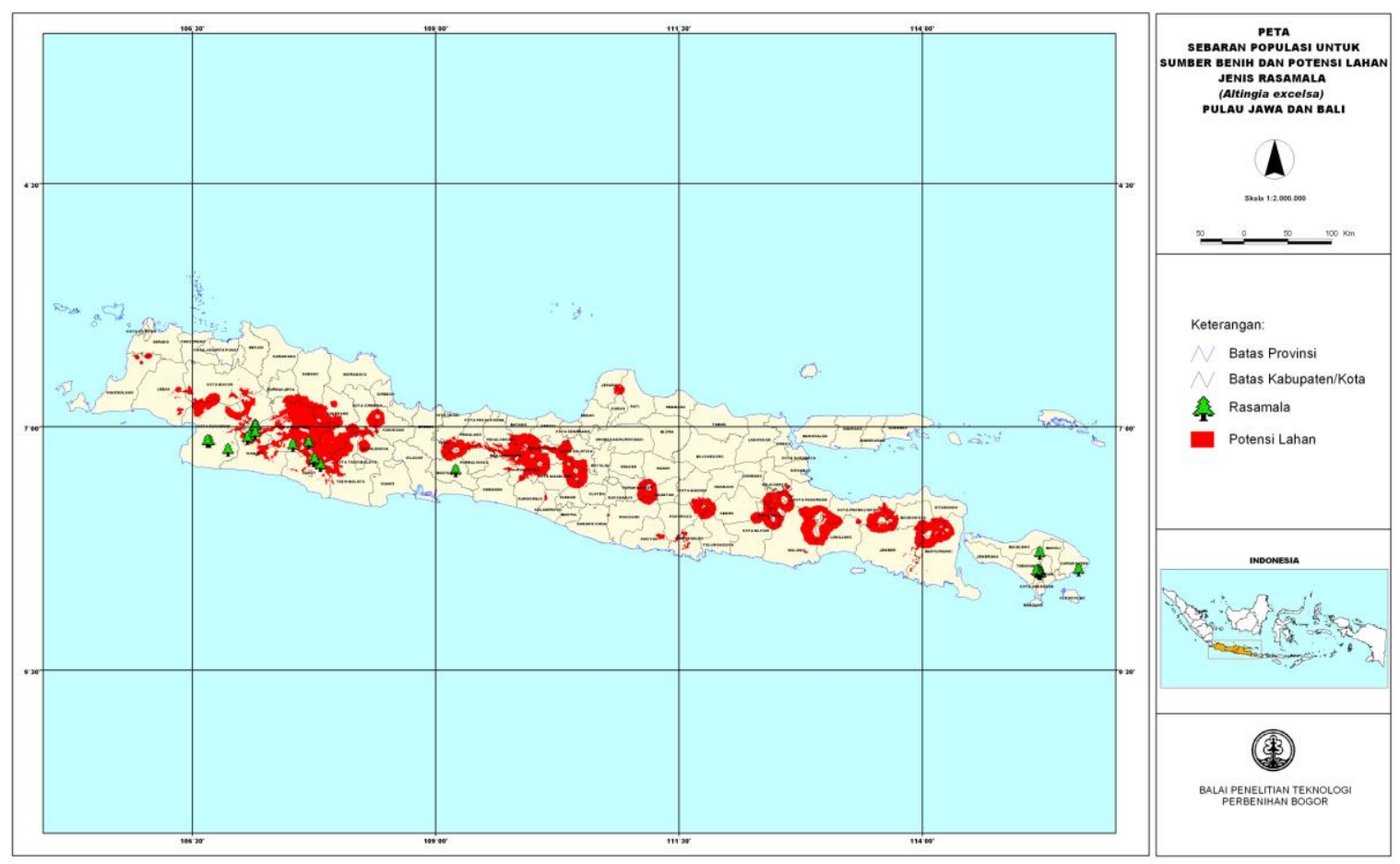

Gambar (Figure) 2. Sebaran dan potensi lahan untuk sumber benih jenis rasamala (A. excelsa) di Jawa (Distribution and land potential for seed source of rasamala in Java) 


\section{B. Pembahasan}

Berdasarkan hasil survei, sebaran populasi rasamala terdapat di Jawa Barat dan Jawa Tengah. Wilayah tersebut memiliki kriteria persyaratan tumbuh (Tabel 3) yaitu jenis tanah Latosol, Litosol, Grumosol, asosiasi Andosol dan Latosol, asosiasi Regosol dan Litosol, serta Mediteran; ketinggian 808-1962 m dpl, dengan curah hujan antara $1500-4300 \mathrm{~mm} / \mathrm{tahun}$. Pertumbuhan rasamala sangat dipengaruhi oleh ketinggian tempat sehingga potensi lahan jenis ini tersebar di daerah-daerah pegunungan. Berdasarkan pengamatan di lapangan, lokasi tempat tumbuh rasamala secara umum berada pada daerah tinggi dan overlap (berasosiasi) dengan tanaman Pinus merkusii.

Secara operasional, daerah-daerah pegunungan ini umumnya lebih banyak ditanami $P$. merkusii dibandingkan dengan tanaman rasamala terutama pada ketinggian 800-1000 $\mathrm{m}$ dpl karena tanaman $P$. merkusii memiliki nilai ekonomi yang lebih tinggi. Hanya pada ketinggian diatas $1000 \mathrm{~m}$ dpl rasamala lebih banyak dikembangkan karena pada ketinggian tersebut pertumbuhan tanaman pinus kurang begitu baik. Dengan demikian, pengembangan sumber benih rasamala lebih memungkinkan pada lokasi ini dengan ketinggian di atas $1000 \mathrm{~m}$ dpl.

Wilayah pengembangan jenis rasamala berdasarkan zona penggunaan benih (IFSP, 2001) termasuk pada zona pegunungan basah, sub zona pegunungan bagian tengah dan barat dengan vegetasi jenis Querqus sundaica, Casuarina junghuhniana, Antidesma curies, Eugenia sp., Gaultheria fragrantissima, Myrica javanica, Hibiscus similis, Vaccicum sp., Rhododendrum javanicum, Anaphalis javanica, Toona sinensis, Dipterocarpus hasseltii, D. gracilis, Shorea javanica, Agathis lorantifolia, Castanopsis spp., Podocarpus imbricatus, Altingia excelsa, Schima walichii, Paraserianthes falcataria, P. lophanta, dan Pinus merkusii ( IFSP, 2001).

Sebaran populasi rasamala yang telah dipetakan diharapkan akan dapat membantu dalam perencanaan pengembangan sumber benih dan program konservasi sumberdaya genetik di wilayah ini. Gradual et al. (2001) menjelaskan bahwa peta sebaran digunakan untuk mengetahui sebaran geografi dan ekologi serta untuk mengetahui keragaman sifat menurun jenis tanaman target baik di hutan alam ataupun hutan tanaman. Dengan adanya peta ini diharapkan pengambilan contoh biji atau bahan vegetatif tanaman terpilih dapat mewakili potensi faktor menurun yang ada di seluruh populasi.

Sebaran potensi lahan hasil analisis SIG (Tabel 4) yaitu seluas 1.193.266,67 ha tersebar di seluruh Pulau Jawa. Walaupun lahan tersebut memiliki persyaratan tumbuh yang cocok untuk jenis ini, namun hanya sebagian lahan pada wilayah Jawa Barat dan Jawa Tengah ditemukan tegakan rasamala. Lahan yang cocok tetapi tidak ditemukan pohon rasamala di lokasi ini cenderung bukan sebaran alaminya dan ada kemungkinan merupakan hutan tanaman dan telah ditebang. Walaupun menurut Beekman (1947) populasi sebaran alami tanaman rasamala di Pulau Jawa terdapat di wilayah Jawa Barat dan Banten, ternyata di lokasi lain seperti daerah Jawa Tengah (Banyumas) tanaman ini tumbuh dengan baik. Dengan demikian, potensi lahan yang tersusun dapat dijadikan dasar untuk pengembangan jenis ini.

Peta sebaran populasi tanaman rasamala di Pulau Jawa ini (Tabel 4 dan Gambar 2) belum menunjukkan secara spesifik wilayah pengembangan untuk masing-masing lokasi tetapi masih merupakan gabungan dari kondisi lokasi populasi rasamala yang diamati. Hal tersebut disebabkan oleh terbatasnya data ekologis dari masing-masing lokasi sehingga penyusunannya lebih bersifat umum. Walaupun demikian peta sebaran ini dapat digunakan sebagai peta potensi lahan dan konsep zona benih yang selanjutnya merupakan zona penggunaan benih. Data potensi lahan dapat digunakan sebagai informasi awal dalam penentuan lokasi sumber benih dan untuk pengembangan hutan tanaman jenis ini (Rohandi et al., 2006). Dengan demikian, diharapkan akan terjadi kesesuaian antara sumber benih dengan lokasi penanaman untuk menunjang keberhasilan penanaman.

Sumber benih rasamala yang telah disertifikasi 118,74 ha yang tersebar di KPH Cianjur dan KPH Sukabumi (BPTH Jawa-Madura, 2006). Sementara itu, hasil penelitian Rohandi et al. (2006) menunjukkan bahwa untuk wilayah Jawa Barat jenis rasamala memiliki wilayah pengembangan yang memusat di empat kabupaten. Hal tersebut disebabkan sumber benih yang ada mengumpul di lokasi tersebut terutama di kabupaten Sukabumi dan Cianjur yang berada di daerah dataran tinggi/pegunungan dan juga merupakan sebaran tumbuh alami jenis ini. Pada lahan ini pertumbuhan tegakan rasamala 
umur 48 tahun di Sukabumi dengan jenis tanah Latosol memiliki tinggi $47 \mathrm{~m}$ dan diameter 48,09 cm, sedangkan tegakan umur 33 tahun di Cianjur dengan jenis tanah Latosol memiliki tinggi $31 \mathrm{~m}$ dan diameter 40,17 cm (Nurhasybi et al., 2000; Danu et al., 2004). Tegakan rasamala yang tumbuh di KPH Garut, KPH Bandung Selatan, dan KPH Banyumas memiliki potensi untuk digunakan sebagai sumber benih baru.

Dalam rangka pengembangan hutan tanaman rasamala perlu dibangun sumber-sumber benih baru. Sumber benih tersebut dapat dibangun dengan cara menunjuk tegakan-tegakan yang sudah ada, sedangkan pada lahan yang belum ada tegakannya dapat dilakukan penanaman sumber benihnya yang disesuaikan dengan zonasinya. Berdasarkan prinsip pokok zona benih, penggunaan benih dari sumber benih yang berbeda harus ditanam pada tempat yang berbeda karena adanya interaksi genotipa dan lingkungan. Tanaman dengan kualitas genetik baik akan menghasilkan fenotipa yang baik apabila ditanam pada kondisi lingkungan yang sesuai. Zona penggunaan benih ini dapat mencakup areal yang luas dan dapat terdiri dari beberapa areal yang memiliki kondisi ekologis yang serupa. Pada zona ini, tanaman memiliki pertumbuhan yang relatif lebih seragam (IFSP, 2001). Pembangunan atau penunjukan sumber benih baru sebaiknya ditempatkan berdasarkan sebaran potensi lahan untuk jenis ini. Benih yang dihasilkan dari sumber benih tersebut dapat digunakan pada seluruh lahan potensial yang telah tersusun.

\section{KESIMPULAN DAN SARAN}

\section{A. Kesimpulan}

1. Sebaran populasi rasamala di Pulau Jawa terletak pada ketinggian 808-1962 m dpl, dengan jenis tanah Latosol, Litosol, Grumosol, asosiasi Andosol dan Latosol, asosiasi Regosol dan Litosol, dan curah hujan 1500-4300 mm/tahun. Lokasi ini tersebar di beberapa lokasi yaitu di KPH Sukabumi, KPH Cianjur, KPH Bandung Selatan, KPH Garut, KPH Banyumas Timur dan Banyumas Barat.

2. Sumber benih rasamala di Pulau Jawa yang telah disertifikasi dan dipetakan yaitu seluas 118,74 ha serta terdapat beberapa populasi yang cukup potensial untuk dikembangkan menjadi sumber benih di daerah Garut, Bandung Selatan dan Banyumas.

3. Potensi lahan jenis rasamala di Pulau Jawa yaitu seluas 1.193.266,67 ha yang tersebar di 37 kabupaten dapat digunakan sebagai wilayah pengembangan hutan tanaman dan informasi awal dalam perencanaan lokasi pengembangan sumber benih jenis ini.

\section{B. Saran}

Peta sebaran populasi dan potensi lahan rasamala ini dapat digunakan sebagai dasar pengembangan sumber benih dan pembangunan hutan tanaman rasamala di Pulau Jawa. Disamping itu, hasil penelitian ini dapat dikembangkan menjadi zonasi benih berdasarkan kriteria yang lebih spesifik seperti jenis tanah, ketinggian, dan curah hujan, atau menambah kriteria lain yang dianggap penting.

\section{DAFTAR PUSTAKA}

Beekman, H.A.J.M. 1947. Perihal Pembudidayaan Tanaman Rasamala (Altingia excelsa Noronhae), Hamamelidaceae. Terjemahan (A.A. Luhiya. 1995). Seri Himpunan Peninggalan Penulisan yang Berserakan. Bandung.

BPTH. 2005. Daftar Lokasi Sumber Benih yang telah Disertifikasi di Wilayah Jawa dan Madura. Balai Perbenihan Tanaman Hutan Jawa-Madura. Sumedang. 
Danu, Nurhasybi, dan Y. Bramasto. 2004. Potensi Produksi Benih di Jawa. Ekspose Terpadu HasilHasil Penelitian. Departemen Kehutanan, Yogyakarta, 11-12 Oktober 2004. Yogyakarta : Badan Penelitian dan Pengembangan Kehutanan. Hlm 1-12.

Direktorat Jenderal Kehutanan. 1979. Vademecum Kehutanan Indonesia. Direktorat Jenderal Kehutanan. Departemen Pertanian. Jakarta.

Direktorat Reboisasi dan Rehabilitasi. 1979. Pedoman Pembuatan Tanaman Rasamala (Altingia excelsa Noronhae). Direktorat Reboisasi dan Rehabilitasi. Departemen Pertanian. Jakarta

Garadual L., E. Kjaer, Agnete T dan Allan B. L. 1997. Perencanaan Program Nasional untuk Konservasi Sumberdaya Genetik Hutan. Technical Note No. 48-Desember 1997. Danida Forest Seed Centre, Krogerupvej 21 DK-3050 Humlaebaek. Denmark.

Hardjowigeno, S. 2003. Ilmu Tanah. Akademika Pressindo. Jakarta.

IFSP. 2001. Zona Benih Tanaman Hutan Jawa dan Madura. Kerjasama Drektorat Perbenihan Tanaman Hutan dengan Indonesia Forest Seed Project. Jakarta.

Kartiko, H.P. 2001. Penyelamatan Sumber Daya Perbenihan untuk Pelestarian dan Peningkatan Produktivitas Tanaman Hutan. Bulletin PUSBANGHUT. Vol. III, 2 Juli 2001 hal. $183-190$. PT. Perhutani. Cepu.

Nienstadt, H. and E.B. Snyder. 1974. Principles of Genetic Improvement of Seed in Schopmeyer, C.S. 1974. Seeds Woody Plants in The United States. Agriculture Handbook No. 450. USDA. Washington, D.C.

Nurhasybi, A.A. Pramono, S. Mokodompit, A.Z. Abidin, A. Rohandi, O. Marom, dan Darmawati F.D. 2000. Peta Perwilayahan 9 (sembilan) Jenis Tanaman Hutan di Jawa. : Bogor : Balai Teknologi Perbenihan. Hlm. 2-13.

Panitia Perancang Hutan Industri. 1958. Hutan Industri. Jawatan Kehutanan Republik Indonesia. pp. 146-148.

Rohandi, A., B. Mulyanto dan U. Wiradisastra. 2006. Strategi Pengembangan Sumber Benih Tanaman Hutan Berbasis Spasial dan Potensi Lahan di Jawa Barat. Program Pasca Sarjana Ilmu Perencanaan Wilayah. Institut Pertanian Bogor. Tesis. Tidak Diterbitkan. Bogor.

Sitorus, S.R.P. 1998. Evaluasi Sumberdaya Lahan. Bandung : Tarsito.

Soewarsono, P.H. 1960. Beberapa Catatan tentang Perbedaan Kayu Puspa (Schima wallichii (DC) KORT) dan Kayu Rasamala (Altingia excelsa NOR.). Lembaga Penelitian Hutan. Bogor. p 7.

Widjajanto, H. 1984. Cara Pencegahan Uret Exopholis hypoleuca Wied. dan Leucopholis rorida F. (hama tanaman muda rasamala) dengan Insektisida BHC (Lindane) di RPH Takokak, BKPH Cikawung, KPH Sukabumi. Skripsi Jurusan Manajemen Hutan. Fakultas Kehutanan IPB, Bogor.

Vink, W. 1957. Hamamelidaceae : Altingia. Flora Malesiana. Ser. 1, Vol. $5^{3}$. p 376-379.

Zobel, B. and J. Talbert. 1984. Applied Forest Tree Improvement. Wave Land Press, Inc. Illinois. USA. 